\title{
Suppression of Specific Apple Root Pathogens by Brassica napus Seed Meal Amendment Regardless of Glucosinolate Content
}

\author{
Mark Mazzola, David M. Granatstein, Donald C. Elfving, and Kent Mullinix
}

First author: USDA-ARS, Wenatchee, WA; second and third authors: Washington State University, TFREC, Wenatchee; and fourth author: Wenatchee Valley College, Wenatchee, WA.

Accepted for publication 28 March 2001.

\begin{abstract}
Mazzola, M., Granatstein, D. M., Elfving, D. C., and Mullinix, K. 2001. Suppression of specific apple root by Brassica napus seed meal amendment regardless of glucosinolate content. Phytopathology 91:673-679.

The impact of Brassica napus seed meal on the microbial complex that incites apple replant disease was evaluated in greenhouse trials. Regardless of glucosinolate content, seed meal amendment at a rate of $0.1 \%$ (vol/vol) significantly enhanced growth of apple and suppressed apple root infection by Rhizoctonia spp. and Pratylenchus penetrans. High glucosinolate B. napus cv. Dwarf Essex seed meal amendments did not consistently suppress soil populations of Pythium spp. or apple root infection by this pathogen. Application of a low glucosinolate containing B. napus seed meal at a rate of $1.0 \%(\mathrm{vol} / \mathrm{vol})$ resulted in a significant

increase in recovery of Pythium spp. from apple roots, and a corresponding reduction in apple seedling root biomass. When applied at lower rates, B. napus seed meal amendments enhanced populations of fluorescent Pseudomonas spp., but these bacteria were not recovered from soils amended with seed meal at a rate of $2 \%(\mathrm{vol} / \mathrm{vol})$. Seed meal amendments resulted in increased soil populations of total bacteria and actinomycetes. B. napus cv. Dwarf Essex seed meal amendments were phytotoxic to apple when applied at a rate of $2 \%(\mathrm{vol} / \mathrm{vol})$, and phytotoxicity was not diminished when planting was delayed for as long as 12 weeks after application. These findings suggest that $B$. napus seed meal amendments can be a useful tool in the management of apple replant disease and, in the case of Rhizoctonia spp., that disease control operates through mechanisms other than production of glucosinolate hydrolysis products.
\end{abstract}

Control of replant diseases of fruit trees has relied upon the use of soil fumigants that possess broad-spectrum biological activities. Preplant soil fumigation has been the standard practice for control of apple replant disease due to uncertainty concerning the primary biological factors that contribute to disease development. The impending phaseout in production and importation of methyl bromide, and potential regulatory restrictions on the use of other soil fumigants, place doubt in the long-term availability of suitable chemical measures for the control of this disease.

Formulation of alternative methods for the control of apple replant disease is hindered by the lack of sufficient knowledge concerning disease etiology. However, recent studies have demonstrated that a fungal complex composed of species of the genera Cylindrocarpon, Phytophthora, Pythium, and Rhizoctonia is the dominant cause of replant disease in Washington, and that in a limited number of instances, plant-parasitic nematodes also contribute significantly to disease development $(12,14)$. These foundations have enabled the formulation and evaluation of nonfumigant methods for the control of apple replant disease.

The chemical fumigant metam sodium controls soilborne pathogens and enhances the growth and yield of apple established in replant orchard soils (31). Metam sodium has methyl isothiocyanate as its active compound, which is produced upon decomposition when applied to moist soil. Members of the plant family Brassicaceae, including Brassica napus, produce glucosinolates, which upon hydrolysis yield biologically active products in-

Corresponding author: M. Mazzola; E-mail address: mazzola@tfrl.ars.usda.gov

Publication no. P-2001-0503-01R

This article is in the public domain and not copyrightable. It may be freely reprinted with customary crediting of the source. The American Phytopathological Society, 2001. cluding isothiocyanates (4). Because glucosinolate hydrolysis products have a broad spectrum of biological activity, recent investigations have focused on the use of these plants as a tool in the management of soilborne plant pathogens. Several studies have demonstrated inhibition of fungal plant pathogens upon exposure to volatiles produced during degradation of glucosinolatecontaining plant residues $(2,23,27)$. Inhibition of $R$. solani and Pythium spp., two elements of the fungal complex that incite apple replant disease, has been achieved through exposure to glucosinolate-derived volatiles (9-11). These findings suggest that incorporation and incubation of Brassicaceae plant residues in orchard soils may be a suitable means to control elements of the microbial complex that incite apple replant disease.

Although Brassicaceae plant residues have demonstrated fungicidal and disease control activity, the need to cultivate such a crop on-site during the process of orchard renovation may not allow for practical implementation into an orchard management system. In the case of $B$. napus, an alternative may be the use of defatted seed meal, which is a by-product of oil extraction. B. napus seed meal amendments to soil provide control of Aphanomyces root rot of pea (27) and may serve as a supplementary nitrogen source (8).

Brassica spp. plant residues incorporated in soil can be phytotoxic to subsequent crops $(22,29)$. Application of B. napus seed meal caused extensive damage and death of 'Gala' on M.26 rootstock when applied directly into the tree hole at time of planting (D. M. Granatstein, unpublished data). Thus, effective use of this material will require information concerning appropriate rates, duration of incubation between application and planting, and the evaluation of other tools that could limit toxicity toward apple.

Methyl isothiocyanate has a transient negative impact on soil bacteria population size (28), and roots of plants grown in treated soils exhibit significant reductions in colonization by mycorrhizal fungi (5). Incorporation of isothiocyanates reduces populations of 
$\mathrm{NH}_{4}{ }^{+}$-oxidizing bacteria, and mineralization of $\mathrm{N}$ in a sandy loam soil was inhibited by the amendment of 2-phenethyl-isothiocyanate (3). In contrast, a green manure of high glucosinolate containing B. napus 'Dwarf Essex' had no apparent impact on populations of total culturable bacteria and fluorescent pseudomonads in the rhizosphere of pea 6 weeks after planting, and did not impact nodulation of pea by $R$. leguminosarum (25). Based on carbon utilization profiles, the amendment of soil with $B$. napus residues did not appear to significantly alter attributes of the microbial community in the pea rhizosphere.

Integrating methods that selectively suppress elements of the complex that incite replant disease with procedures that enhance activity of resident microbial antagonists is a goal of this research program. In greenhouse trials, planting orchard replant soils to certain wheat cultivars enhanced subsequent growth of apple (16). The ability of a wheat cultivar to enhance growth of apple in replant soils appears to be induced indirectly through the activity of resident soil microbial antagonists because the growth response was associated with changes in composition of the fluorescent pseudomonad population as well as increased recovery of Fusarium spp. and actinomycetes from apple roots (16; M. Mazzola and Y.-H. Gu, unpublished data). However, the apple growth response achieved through soil pasteurization typically was superior to that obtained in response to prior cultivation of soils with wheat, indicating that this practice will not be a stand alone replacement to soil fumigation for control of replant disease. Effective integration of wheat cover cropping with the incorporation of glucosinolate-containing plant residues for the control of apple replant disease depends upon the impact of glucosinolate hydrolysis products on plant beneficial microbial communities.

In the current study, the impact of B. napus seed meal amendments on growth of apple seedlings in orchard replant soils was assessed, and the effect of such amendments on populations of specific soil microorganisms was determined.

\section{MATERIALS AND METHODS}

Orchard soils used in growth assays. Studies were conducted in soils from the Columbia View Experimental (CV) orchard located $19.2 \mathrm{~km}$ north of East Wenatchee, WA, and the Wenatchee Valley College Auvil Research and Demonstration (WVC-A) orchard located $6.4 \mathrm{~km}$ east of East Wenatchee, WA. Replant disease potential was mild to moderate at the $\mathrm{CV}$ orchard and moderate to severe at the WVC-A orchard based on relative increase in growth of apple seedlings and 'Gala' on M.26 rootstock in response to steam pasteurization or preplant soil fumigation with methyl bromide, respectively $(12,13,15)$. The primary incitants of replant disease are $C$. destructans and $R$. solani at the $\mathrm{CV}$ orchard and $R$. solani at the WVC-A orchard. (12,14). A composite sample was obtained from each site by collecting soil at a depth of 10 to $30 \mathrm{~cm}$ within the orchard rows in September 1998 and October 1999. Soils were stored in 113-liter covered cans at $4^{\circ} \mathrm{C}$ until use.

TABLE 1. Glucosinolate content (micromole per gram) of Brassica napus seed meal

\begin{tabular}{lcc}
\hline Glucosinolate & 'Dwarf Essex' & Canola \\
\hline 3-Butenyl & 95.5 & 6.7 \\
4-Pentenyl & 1.3 & 2.5 \\
2-OH-3-butenyl & 10.5 & 9.2 \\
2-OH-4-pentenyl & 0.2 & 0.6 \\
4-Methylthiobutyl & 0.5 & 0.3 \\
Phenylethyl & 0.5 & 0.4 \\
5-Methylthiopentyl & 0.4 & 0.3 \\
3-Indolymethyl & 0.1 & 0.3 \\
4-OH-3-indolylmethyl & 1.0 & 0.7 \\
4-Methylsulfinylbutyl & 2.5 & 0.6 \\
5-Methylsulfinylpentyl & 1.2 & 1.0 \\
\hline
\end{tabular}

Preparation of seedlings for growth assays. Apple seeds (cv. Gala) were surface sterilized with $10 \%$ commercial bleach $(5.25 \%$ sodium hypochlorite) and rinsed for 30 min under a constant stream of tap water. Seeds were dusted with Captan 50WP and stratified for germination by placing seed in a plastic bag with moistened paper towels at $4^{\circ} \mathrm{C}$ for 8 weeks. Stratified seed were sown into a sterile peat/perlite mix and incubated at $24^{\circ} \mathrm{C}$ with a 12-h photoperiod. After 2 weeks, plants were transferred to environmental growth chambers and grown at $18^{\circ} \mathrm{C}$ with a $12-\mathrm{h}$ photoperiod for 4 weeks. These 6 -week-old seedlings were used in plant growth assays.

B. napus seed meal amendments. Two distinct seed meals varying in glucosinolate content were used in these studies: $B$. napus cv. Dwarf Essex (Montana Vegetable Oils, Great Falls) and a B. napus seed meal of unknown cultivar marketed as canola meal (Integrated Fertility Management, Wenatchee, WA) for use as a fertilizer by organic tree fruit producers. Tissue analysis (Soiltest Farm Consultants, Inc., Moses Lake, WA) demonstrated that both materials contained similar levels of total nitrogen $(6.0 \%)$, sulfur (1.4\%), phosphorous (1.3\%), and potassium $(1.5 \%)$. Glucosinolate composition and content of the seed meal were determined by P. D. Brown (University of Idaho, Moscow) as previously described (27). Glucosinolate composition was similar, but 'Dwarf Essex' seed meal was very high in glucosinolate content, with 3-butenyl glucosinolate dominating, and glucosinolate content of the canola seed meal was relatively low (Table 1).

Plant growth assays and analysis of soil microorganisms. Experiments were conducted in WVC-A orchard soils collected in 1998 to examine the impact of seed meal glucosinolate content on disease suppression and growth of apple. 'Dwarf Essex' or canola seed meal was incorporated into soils at a rate of 0.1 or $1.0 \%$ $(\mathrm{vol} / \mathrm{vol})$ and incubated for 6 weeks prior to planting apple seedlings.

The impact of seed meal amendment rate and length of incubation period prior to planting on growth of apple was evaluated in trials conducted in both CV and WVC-A replant orchard soils collected in 1998 and 1999. 'Dwarf Essex' seed meal amendments were made at a rate of $0.1,1.0$, or $2.0 \%(\mathrm{vol} / \mathrm{vol})$, and soils were incubated in the greenhouse for 4,8 , or 12 weeks prior to planting.

Experimental controls included nontreated and pasteurized soils. Pasteurization was conducted in a 50-liter metal canister that connected by rubber hosing to a steam source. Soils were pasteurized for $90 \mathrm{~min}$ at a temperature of $95^{\circ} \mathrm{C}$.

Plant growth assays were conducted in the greenhouse at $20 \pm$ $3^{\circ} \mathrm{C}$ with supplemental lighting to maintain a 12 -h photoperiod. Treated and nontreated CV and WVC-A orchard replant soils were placed in 3.8-liter plastic pots and planted to five 6-week-old 'Gala' apple seedlings per pot, with five pots per treatment. Seedlings were harvested 12 weeks after planting. At harvest, plants were removed from pots and root systems were washed under a stream of tap water. Root systems were blotted dry with paper towels, and plant height, shoot weight, and root weight were measured.

TABLE 2. Impact of Brassica napus seed meal amendments on growth of 'Gala' apple seedlings in replant soils from the Wenatchee Valley CollegeAuvil orchard, WAy

\begin{tabular}{lccc}
\hline Treatment $^{\mathrm{z}}$ & Root weight $(\mathrm{g})$ & Shoot weight $(\mathrm{g})$ & Shoot length $(\mathrm{cm})$ \\
\hline Control & $0.71 \mathrm{~b}$ & $0.80 \mathrm{a}$ & $7.4 \mathrm{a}$ \\
Pasteurization $\left(95^{\circ} \mathrm{C}\right)$ & $1.89 \mathrm{~d}$ & $3.21 \mathrm{~d}$ & $19.4 \mathrm{~d}$ \\
$0.1 \%$ 'Dwarf Essex' & $0.98 \mathrm{c}$ & $1.54 \mathrm{~b}$ & $13.7 \mathrm{~b}$ \\
$0.1 \% \mathrm{C}$ & $0.73 \mathrm{~b}$ & $1.89 \mathrm{bc}$ & $14.4 \mathrm{bc}$ \\
$1.0 \%$ 'Dwarf Essex' & $1.10 \mathrm{c}$ & $2.41 \mathrm{c}$ & $16.4 \mathrm{~cd}$ \\
$1.0 \% \mathrm{C}$ & $0.47 \mathrm{a}$ & $1.58 \mathrm{~b}$ & $11.9 \mathrm{~b}$
\end{tabular}

${ }^{y}$ Soils were incubated for 6 weeks after application of treatments and planted to 6-week-old seedlings. Means in the same column followed by the same letter are not significantly different $(P=0.05)$ based on the Student-NewmanKeuls test.

${ }^{\mathrm{z}} \mathrm{C}=$ unknown cultivar marketed as canola meal. 
A 50-ml soil sample was collected from each pot immediately prior to planting apple seedlings. For each pot, a 5-g subsample was placed in an oven at $80^{\circ} \mathrm{C}$ for $72 \mathrm{~h}$ to determine soil dry weight. Populations of Pythium spp. were determined by suspending $5 \mathrm{~g}$ of soil in $25 \mathrm{ml}$ of sterile water and plating serial dilutions on a medium semiselective for pythiaceous fungi (1/10th-strength potato dextrose agar, $75 \mu \mathrm{g} \mathrm{m}{ }^{-1}$ of rifampicin, $0.5 \mu \mathrm{g}$ a.i. $\mathrm{ml}^{-1}$ of benomyl, and $1.0 \mu \mathrm{g}$ a.i. $\mathrm{ml}^{-1}$ of difenconazole), with two replicate plates per dilution and two 5-g subsamples per pot. Plates were incubated at room temperature $\left(20\right.$ to $\left.23^{\circ} \mathrm{C}\right)$, and colonies were counted after 48 and $72 \mathrm{~h}$. Populations of total bacteria, actinomycetes, and fluorescent pseudomonads were estimated by plating serial dilutions of the soil suspension onto 1/10thstrength tryptic soy agar (TSA), 1/50th-strength TSA, and King's medium $\mathrm{B}^{+}$agar (26), respectively. Plates were incubated at $28^{\circ} \mathrm{C}$, and colonies were enumerated and differentiated after $72 \mathrm{~h}$ for total bacteria and fluorescent pseudomonads, and after 6 days for actinomycetes.

Composition of the fungal community colonizing apple roots was determined at harvest. Ten root segments ( 0.5 to $1.0 \mathrm{~cm}$ long) from each seedling were excised and plated on $1.5 \%$ water agar amended with ampicillin $\left(100 \mu \mathrm{g} \mathrm{ml}^{-1}\right)$. After incubation at room temperature $\left(20\right.$ to $23^{\circ} \mathrm{C}$ ) for $96 \mathrm{~h}$, fungal growth from root segments was examined by a light microscope $(\times 100)$. Fungi were identified to genus, and presence of actinomycetes in the same root segments was determined.

Root populations of Pratylenchus penetrans were determined from one randomly selected seedling in each pot. The seedling root system was excised from the shoot, and $0.5 \mathrm{~g}$ of root tissue was placed in $80 \mathrm{ml}$ of sterile deionized water in 125-ml flasks and incubated on a Gyrotory shaker (Model G2; New Brunswick Scientific Co., Edison, NJ) at $200 \mathrm{rpm}$ for $72 \mathrm{~h}$. Nematodes were collected by filtering the root extract twice through a $45-\mu \mathrm{m}$ mesh sieve and backwashing into a counting dish. Numbers of Pratylenchus penetrans were determined by observation $(\times 40)$ with a dissecting microscope.

Soil and leaf mineral analysis. Leaf mineral analysis $(P, K, S$, and total $\mathrm{N}$ ) and determination of soil nitrogen were performed by Soiltest Farm Consultants, Inc. (Moses Lake, WA). For each treatment, a 100-ml soil sample was collected from each pot at planting. At the time of sampling, seed meal amendments had been incubated in soil for 4 or 6 weeks. At harvest, a composite leaf sample $(5 \mathrm{~g})$ was collected for each individual pot after determination of seedling biomass. Five soil and leaf samples were analyzed per treatment.

Statistical analysis. Plant growth and microbial population data were subjected to one-way or two-way analysis of variance, and treatment comparisons were made with the Student-NewmanKeuls test. Percent data for recovery of microbial groups from apple seedling roots were transformed to arcsine-square root values, and soil population data were transformed to $\log _{10}$ values prior to analysis. Statistical analyses were conducted using SigmaStat, version 2.0 (SPSS, San Rafael, CA). All experiments were repeated, and similar results were obtained in the replicated trials. For each study, data shown are from the initial trial.

\section{RESULTS}

Growth of apple in response to $B$. napus seed meal amendments varying in glucosinolate content. Growth of apple in WVC-A orchard replant soil amended with B. napus seed meal varied with the type and rate of seed meal application. At a rate of $0.1 \%$, seed meal amendments significantly enhanced apple shoot length and shoot weight, but only 'Dwarf Essex' seed meal amendments improved seedling root biomass (Table 2). At a rate of $1.0 \%$, seedling height and biomass was significantly greater in 'Dwarf Essex' than in canola seed meal-amended soils. Application of $1.0 \%$ canola seed meal resulted in a significant reduction in apple seedling root biomass relative to the control. Apple shoot biomass was greater for seedlings grown in soils amended with 'Dwarf Essex' seed meal at $1.0 \%$ than at $0.1 \%$.

Impact of amendment rate and incubation period on growth of apple. A significant interaction between length of incubation period prior to planting and seed meal concentration was observed for all seedling growth parameters in CV and WVCA orchard replant soils (Table 3). Varying the duration of the incubation period from 4 to 12 weeks did not impact growth of seedlings in soils amended with seed meal at 0.1 or $1.0 \%$, but biomass of seedlings grown in soils amended with $2 \%$ seed meal declined with increasing incubation period prior to planting. All seedling growth parameters were significantly enhanced by 'Dwarf Essex' seed meal amendments at a rate of 0.1 or $1.0 \%$ prior to planting in CV and WVC-A orchard replant soils (Table 4). The growth response was greater when 'Dwarf Essex' seed meal was applied at a rate of $1.0 \%$ than at $0.1 \%$. In contrast, apple root biomass was significantly reduced in WVC-A soil amended with seed meal at a concentration of $2 \%$, and this could partly be attributed to seedling mortality. Although root biomass of seedlings grown in CV soil amended with $2 \%$ seed meal was not

TABLE 4. Impact of Brassica napus cv. Dwarf Essex seed meal amendments on growth of 'Gala' apple seedlings in soils from the Columbia View (CV) and Wenatchee Valley College-Auvil (WVC-A) orchards, WA ${ }^{\mathrm{z}}$

\begin{tabular}{lccc}
\hline Treatment & Root weight $(\mathrm{g})$ & Shoot weight $(\mathrm{g})$ & Shoot height $(\mathrm{cm})$ \\
\hline CV orchard soil & & & \\
Control & $0.54 \mathrm{a}$ & $1.20 \mathrm{a}$ & $13.3 \mathrm{a}$ \\
Pasteurization $\left(95^{\circ} \mathrm{C}\right)$ & $2.01 \mathrm{~d}$ & $3.69 \mathrm{c}$ & $20.4 \mathrm{~b}$ \\
$0.1 \%$ seed meal & $1.27 \mathrm{~b}$ & $2.76 \mathrm{~b}$ & $19.4 \mathrm{~b}$ \\
$1.0 \%$ seed meal & $1.65 \mathrm{c}$ & $5.26 \mathrm{~d}$ & $26.5 \mathrm{c}$ \\
$2.0 \%$ seed meal & $0.51 \mathrm{a}$ & $2.04 \mathrm{~b}$ & $14.1 \mathrm{a}$ \\
WVC-A orchard soil & & & \\
Control & $1.01 \mathrm{~b}$ & $0.96 \mathrm{a}$ & $8.5 \mathrm{a}$ \\
Pasteurization $\left(95^{\circ} \mathrm{C}\right)$ & $1.72 \mathrm{c}$ & $3.52 \mathrm{~b}$ & $17.0 \mathrm{c}$ \\
$0.1 \%$ seed meal & $2.13 \mathrm{~d}$ & $3.19 \mathrm{~b}$ & $15.1 \mathrm{bc}$ \\
$1.0 \%$ seed meal & $1.92 \mathrm{~cd}$ & $5.64 \mathrm{c}$ & $21.6 \mathrm{~d}$ \\
$2.0 \%$ seed meal & $0.43 \mathrm{a}$ & $1.56 \mathrm{a}$ & $11.2 \mathrm{ab}$ \\
\hline
\end{tabular}

z Values were obtained by averaging across all incubation periods, which ranged from 4 to 12 weeks after application of seed meal to soils prior to planting apple. Means in the same column followed by the same letter are not significantly different $(P=0.05)$ based on the Student-NewmanKeuls test.

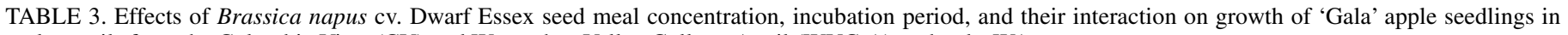
replant soils from the Columbia View (CV) and Wenatchee Valley College-Auvil (WVC-A) orchards, WA

\begin{tabular}{|c|c|c|c|c|c|c|}
\hline \multirow[b]{2}{*}{ Source } & \multicolumn{2}{|c|}{ Shoot length } & \multicolumn{2}{|c|}{ Shoot weight } & \multicolumn{2}{|c|}{ Root weight } \\
\hline & $F$ & $P>F$ & $F$ & $P>F$ & $F$ & $P>F$ \\
\hline \multicolumn{7}{|l|}{$\mathrm{CV}$ orchard } \\
\hline Rapeseed rate $(\mathrm{R})$ & 26.68 & 0.0001 & 42.12 & 0.0001 & 37.16 & 0.0001 \\
\hline Incubation period (I) & 1.24 & 0.2906 & 0.82 & 0.4499 & 1.90 & 0.1511 \\
\hline $\mathrm{R}-\mathrm{I}$ & 5.81 & 0.0001 & 6.02 & 0.0001 & 2.86 & 0.0232 \\
\hline \multicolumn{7}{|l|}{ WVC-A orchard } \\
\hline Rapeseed rate $(\mathrm{R})$ & 53.91 & 0.0001 & 72.65 & 0.0001 & 79.8 & 0.0001 \\
\hline Incubation period (I) & 1.80 & 0.1667 & 1.95 & 0.1447 & 1.56 & 0.2573 \\
\hline R-I & 7.28 & 0.0001 & 8.02 & 0.0001 & 7.18 & 0.0001 \\
\hline
\end{tabular}


different than the control, it was significantly less than that obtained in soils amended at a rate of 0.1 or $1.0 \%$. Duration of incubation had no significant $(P=0.05)$ impact on seedling mortality. Seed meal amendment at a rate of 0.1 or $1.0 \%$ did not alter seedling survival. In contrast, a significant increase in seedling death was observed in soils amended at a rate of $2.0 \%$, with seedling mortality ranging from 58 to $70 \%$ and 68 to $84 \%$ in $\mathrm{CV}$ and WVC-A soils, respectively.

Impact of $B$. napus seed meal amendments on soil microorganisms. Prior to application of seed meal, total bacteria populations in $\mathrm{CV}$ orchard soil were approximately $10^{7} \mathrm{CFU} \mathrm{g} \mathrm{g}^{-1}$ and increased to greater than $10^{8} \mathrm{CFU} \mathrm{g}^{-1} 4$ weeks after application of 'Dwarf Essex' seed meal at a rate of 1.0 or $2.0 \%$. In the same soil, fluorescent pseudomonad populations increased significantly (from $3.9 \times 10^{5}$ to $2.3 \times 10^{6} \mathrm{CFU} \mathrm{g}^{-1}$ ) in response to application of 'Dwarf Essex' seed meal at a rate of $0.1 \%$, but declined dramatically when higher rates were applied and were below the level of detection $\left(10^{2} \mathrm{CFU} \mathrm{\textrm {g } ^ { - 1 }}\right.$ of soil) in soils amended with $2.0 \%$ seed meal. Actinomycete populations were approximately $10^{6} \mathrm{CFU} \mathrm{g}^{-1}$ in nontreated soil and soil amended with $2 \%$ seed meal, but were greater than $10^{7} \mathrm{CFU} \mathrm{g}{ }^{-1}$ in soils amended with seed meal at a rate of 0.1 or $1.0 \%$. Prior to planting, the actinomycete population in pasteurized soil was below the level of detection $\left(10^{3} \mathrm{CFU} \mathrm{g} \mathrm{g}^{-1}\right.$ of soil).

'Dwarf Essex' and canola seed meal applications had similar impacts on total bacteria and fluorescent pseudomonad populations in WVC-A orchard soil. Seed meal amendments at a rate of $0.1 \%$ increased soil populations of total bacteria and fluorescent pseudomonads (Table 5). As observed in CV orchard soil, amendment of either seed meal at a rate of $1.0 \%$ significantly depressed fluorescent pseudomonad populations.

TABLE 5. Impact of Brassica napus seed meal amendments on populations (log CFU per gram of soil) of total culturable bacteria, fluorescent pseudomonads, and Pythium spp. (propagules per gram of soil) in replant soils from the Wenatchee Valley College-Auvil orchard, WA ${ }^{z}$

\begin{tabular}{lccc}
\hline Treatment & $\begin{array}{c}\text { Total } \\
\text { bacteria }\end{array}$ & $\begin{array}{c}\text { Fluorescent } \\
\text { pseudomonads }\end{array}$ & Pythium spp. \\
\hline Control & $7.36 \mathrm{a}$ & $5.94 \mathrm{~b}$ & $146 \mathrm{~b}$ \\
Pasteurization $\left(95^{\circ} \mathrm{C}\right)$ & $9.02 \mathrm{~b}$ & $6.72 \mathrm{c}$ & $0 \mathrm{a}$ \\
$0.1 \%$ 'Dwarf Essex' & $8.57 \mathrm{~b}$ & $7.51 \mathrm{~d}$ & $40 \mathrm{a}$ \\
$0.1 \%$ C & $8.42 \mathrm{~b}$ & $6.84 \mathrm{~cd}$ & $108 \mathrm{ab}$ \\
$1.0 \%$ 'Dwarf Essex' & $8.98 \mathrm{~b}$ & $3.79 \mathrm{a}$ & $50 \mathrm{a}$ \\
$1.0 \% \mathrm{C}$ & $8.82 \mathrm{~b}$ & $3.10 \mathrm{a}$ & $783 \mathrm{c}$ \\
\hline
\end{tabular}

${ }^{z}$ Population size was determined 6 weeks after application of soil treatment, immediately prior to planting with 'Gala' apple seedlings. $\mathrm{C}=$ unknown cultivar marketed as canola meal. Means in the same column followed by the same letter are not significantly different $(P=0.05)$ based on the Student-Newman-Keuls test.
A differential response in Pythium spp. populations was observed in soils amended with $B$. napus seed meals varying in glucosinolate content. 'Dwarf Essex' seed meal amendments had an inconsistent, though typically minor, impact on the population size of Pythium spp. (Table 5). In contrast, application of canola seed meal at a rate of $1.0 \%$ resulted in a significant increase in recovery of Pythium spp. from WVC-A orchard soil (Table 5).

Populations of Pratylenchus penetrans averaged 98 and $24 \mathrm{~g}$ per root for seedlings grown in nontreated WVC-A and CV orchard soils, respectively. In WVC-A orchard soil, B. napus seed meal amendments suppressed nematode populations, and Pratylenchus penetrans was not recovered from seedlings grown in soils amended with 'Dwarf Essex' or canola seed meal, regardless of the rate applied. Root populations of Pratylenchus penetrans were not significantly reduced by 'Dwarf Essex' seed meal applications to CV orchard soil, and averaged 10.6, 4.8, and $4.5 \mathrm{~g}$ per root in soils amended at a rate of $0.1,1.0$, and $2.0 \%$, respectively.

Frequency of apple root colonization by the dominant fungal genera and actinomycetes resident to orchard soils varied with amendment type and rate at which the materials were applied. When applied to CV soil, 'Dwarf Essex' seed meal suppressed colonization of apple roots by Cylindrocarpon spp., but the same treatment applied to WVC-A soil had no impact or enhanced root colonization by these fungi (Table 6). Colonization of apple roots by Cylindrocarpon spp. was significantly higher in canola seed meal-amended soils than in soil amended with 'Dwarf Essex' seed meal at the same rates (Table 7). Regardless of glucosinolate content, seed meal amendments significantly suppressed infection of apple seedling roots by Rhizoctonia spp. (Tables 6 and 7). Recovery of actinomycetes from apple seedling roots typically was enhanced in response to seed meal applications. However, frequency of actinomycete isolation was significantly lower from seedlings grown in $2 \%$ seed meal-amended soils than in the same soils receiving a 0.1 or $1.0 \%$ seed meal amendment. Recovery of Fusarium spp. from apple roots was enhanced by 'Dwarf Essex' but not canola seed meal amendments. A striking difference between the two seed meal amendments was the dramatic increase in recovery of Pythium spp. from the roots of apple grown in soil amended with $1.0 \%$ canola seed meal (Table 7).

Impact of treatments on soil nitrogen and leaf mineral content. Pasteurization and application of $0.1 \%$ 'Dwarf Essex' or canola seed meal did not have a significant impact on total nitrogen content, as determined after incubation of soil for 4 to 6 weeks. Total nitrogen in soils receiving seed meal amendments at a rate of $1.0 \%$ or higher was significantly greater than that present in nontreated orchard soils at the time of planting. When applied at the same rate, total nitrogen content in WVC-A orchard soil amended with 'Dwarf Essex' or canola seed meals were

TABLE 6. Impact of Brassica napus cv. Dwarf Essex seed meal amendments on relative recovery of dominant fungal genera and actinomycetes from roots of 'Gala' apple seedlings grown in replant soils from the Columbia View (CV) and Wenatchee Valley College-Auvil (WVC-A) orchards, WA ${ }^{\mathrm{z}}$

\begin{tabular}{|c|c|c|c|c|c|}
\hline Treatment & Cylindrocarpon & Fusarium & Pythium & Rhizoctonia & Actinomycetes \\
\hline \multicolumn{6}{|l|}{$\mathrm{CV}$ orchard } \\
\hline Control & $48.2 \mathrm{c}$ & $4.0 \mathrm{a}$ & $3.8 \mathrm{a}$ & $6.1 \mathrm{~b}$ & $11.5 \mathrm{a}$ \\
\hline Pasteurization $\left(95^{\circ} \mathrm{C}\right)$ & $1.5 \mathrm{a}$ & $16.5 \mathrm{~b}$ & $0 \mathrm{a}$ & $0 \mathrm{a}$ & $20.1 \mathrm{a}$ \\
\hline $1.0 \%$ seed meal & $26.0 \mathrm{~b}$ & $32.7 \mathrm{c}$ & $2.7 \mathrm{a}$ & $0 \mathrm{a}$ & $50.4 \mathrm{c}$ \\
\hline $2.0 \%$ seed meal & $29.1 \mathrm{~b}$ & $49.6 \mathrm{~d}$ & $1.7 \mathrm{a}$ & $0 \mathrm{a}$ & $34.8 \mathrm{~b}$ \\
\hline \multicolumn{6}{|l|}{ WVC-A orchard } \\
\hline $1.0 \%$ seed meal & $28.5 \mathrm{c}$ & $35.3 \mathrm{c}$ & $2.2 \mathrm{a}$ & $0 \mathrm{a}$ & $33.8 \mathrm{~cd}$ \\
\hline $2.0 \%$ seed meal & $11.6 \mathrm{~b}$ & $30.9 \mathrm{c}$ & $1.9 \mathrm{a}$ & $0.1 \mathrm{a}$ & $19.3 \mathrm{ab}$ \\
\hline
\end{tabular}

${ }^{\mathrm{z}}$ Values are the percentage of root segments colonized by the respective organism. Means in the same column followed by the same letter are not significantly different $(P=0.05)$ based on the Student-Newman-Keuls test. 
equivalent (data not shown). Total $\mathrm{N}$ content in leaves of apple seedlings grown in orchard soils amended with 'Dwarf Essex' seed meal at 1 or $2 \%$ was significantly higher than that of seedlings grown in nontreated soil (Table 8). Total $\mathrm{P}$ content was commonly enhanced by seed meal amendments of 1 or $2 \%$. Application of $0.1 \%$ seed meal and soil pasteurization had no detectable impact on leaf mineral content of apple seedlings grown in orchard replant soils.

\section{DISCUSSION}

B. napus seed meal amendments had significant impacts on plant growth and populations of soil microorganisms colonizing the roots of apple grown in orchard replant soils. Growth effects were either positive or negative depending upon rates applied, and resulted from disease control, enhanced plant nutrition, and allelopathic interactions. At the lowest rate applied, enhanced growth appeared to occur primarily because of disease suppression. No significant change in total soil $\mathrm{N}$ at the time of planting or leaf mineral content at harvest were observed in response to B. napus seed meal amendments $(0.1 \%)$, but suppression of apple root infection by Rhizoctonia spp. and, in certain cases, Cylindrocarpon spp. were documented. Seedling root populations of Pratylenchus penetrans were suppressed by $0.1 \%$ 'Dwarf Essex' seed meal amendments. In contrast, at a rate of $1.0 \%$, enhanced plant growth resulted from multiple factors. Disease suppression typically was equivalent or superior to that obtained in response to the lower rate. Enhanced plant growth could be attributed to improved plant nutrition, based on leaf mineral analysis, as well as the observation that shoot biomass and length of seedlings grown in these soils were often greater than that achieved in the absence of significant disease (pasteurized treatment).

$B$. napus seed meal amendments were phytotoxic to apple at higher concentrations, with mortality of the majority of seedlings consistently observed at a soil amendment rate of $2 \%$ ( $\mathrm{vol} / \mathrm{vol})$. Phytotoxicity of rape residues has been reported previously $(21,25)$, and we have observed similar results in orchard trials with M.26 rootstock. A delay in planting after application of plant residues has been recommended to alleviate phytotoxicity. However, in our study a delay of up to 12 weeks between seed meal application and planting did not significantly reduce seedling mortality. This finding suggests that attempts to utilize B. napus seed meal to control soilborne pathogens during orchard renovation may require application at the time of tree removal the year prior to planting in order to minimize the potential for phytotoxicity. Alternatively, application of lower rates may provide useful levels of disease control without phytotoxicity.

Although $R$. solani and Pratylenchus penetrans were suppressed by both B. napus seed meals, Pythium spp. populations increased significantly in response to low glucosinolate canola seed meal amendments. The control of plant-parasitic nematodes and the differential suppression of plant-pathogenic fungi observed in this study in response to Brassica spp. plant residue amendments are consistent with previous reports. Brassica spp. green manure crops reduced populations of Tylenchulus semipene- trans and Paratrichodorus spp. in the roots of orange seedlings but failed to enhance seedling growth. This was attributed to an increase in soil populations of Pythium spp. in response to incorporation of $B$. napus or $B$. juncea green manures and a corresponding increase in root infection by Pythium ultimum (30). Papavizas (21) demonstrated control of Aphanomyces root rot using cabbage leaf amendments, but observed an increase in Rhizoctonia root rot. Disparity in fungal suppression in response to different Brassicaceae amendments should not be unexpected given the diversity in content and composition of glucosinolates produced by members of this plant family and differences in relative toxicity of these compounds $(10,11)$.

Previous studies suggest that glucosinolate hydrolysis products from various plants in the family Brassicaceae inhibit growth of Pythium spp. (6) and provide disease control. Although populations were relatively low in both orchard soils, an inconsistent response in Pythium spp. populations was observed after application of the high glucosinolate containing 'Dwarf Essex' seed meal. This variable response may result, in part, from the fact that as many as 15 different species of Pythium are associated with apple (18), and the relative sensitivity of fungi to the same isothiocyanate varies among species (20).

Glucosinolate hydrolysis products from B. napus 'Dwarf Essex', but not the low glucosinolate content cv. Stonewall, completely inhibited pea root infection by Aphanomyces euteiches f. sp. pisi oospores (27). However, in our study suppression of Rhizoctonia spp. was observed in response to soil amendments of either 'Dwarf Essex' or canola seed meal. The canola meal used in our study contains relatively low glucosinolate levels and substantially lower concentrations than 'Dwarf Essex' seed meal. This finding questions the role that glucosinolate hydrolysis products play in the suppression of Rhizoctonia spp. root infection. It is unlikely that this resulted simply from a fertilization effect, because soils and leaf mineral content of seedlings were not significantly altered by seed meal amendments at a rate of $0.1 \%$, but root

TABLE 8. Impact of Brassica napus cv. Dwarf Essex seed meal amendments on leaf mineral content of 'Gala' apple seedlings grown in replant soils from the Columbia View (CV) and Wenatchee Valley College-Auvil (WVC-A) orchards, WA ${ }^{\mathrm{z}}$

\begin{tabular}{lllll}
\hline Treatment & $\% \mathrm{~N}$ & $\% \mathrm{P}$ & $\% \mathrm{~K}$ & $\% \mathrm{~S}$ \\
\hline CV orchard & & & & \\
Control & $1.22 \mathrm{a}$ & $0.17 \mathrm{ab}$ & $1.58 \mathrm{a}$ & $0.11 \mathrm{a}$ \\
Pasteurization $\left(95^{\circ} \mathrm{C}\right)$ & $1.19 \mathrm{a}$ & $0.16 \mathrm{a}$ & $1.75 \mathrm{a}$ & $0.13 \mathrm{a}$ \\
$0.1 \%$ seed meal & $1.38 \mathrm{a}$ & $0.14 \mathrm{a}$ & $1.48 \mathrm{a}$ & $0.12 \mathrm{a}$ \\
$1.0 \%$ seed meal & $2.05 \mathrm{~b}$ & $0.20 \mathrm{ab}$ & $1.72 \mathrm{a}$ & $0.17 \mathrm{~b}$ \\
$2.0 \%$ seed meal & $2.40 \mathrm{c}$ & $0.23 \mathrm{~b}$ & $1.83 \mathrm{a}$ & $0.20 \mathrm{~b}$ \\
WVC-A orchard & & & & \\
Control & $1.71 \mathrm{a}$ & $0.15 \mathrm{a}$ & $1.50 \mathrm{ab}$ & $0.13 \mathrm{ab}$ \\
Pasteurization & $1.86 \mathrm{a}$ & $0.15 \mathrm{a}$ & $1.80 \mathrm{~b}$ & $0.13 \mathrm{ab}$ \\
$0.1 \%$ seed meal & $1.71 \mathrm{a}$ & $0.13 \mathrm{a}$ & $1.34 \mathrm{a}$ & $0.11 \mathrm{a}$ \\
$1.0 \%$ seed meal & $3.33 \mathrm{~b}$ & $0.23 \mathrm{~b}$ & $1.80 \mathrm{~b}$ & $0.14 \mathrm{ab}$ \\
$2.0 \%$ seed meal & $3.78 \mathrm{c}$ & $0.30 \mathrm{c}$ & $1.77 \mathrm{~b}$ & $0.16 \mathrm{~b}$ \\
\hline
\end{tabular}

${ }^{\mathrm{z}}$ Means in the same column followed by the same letter are not significantly different $(P=0.05)$ based on the Student-Newman-Keuls test.

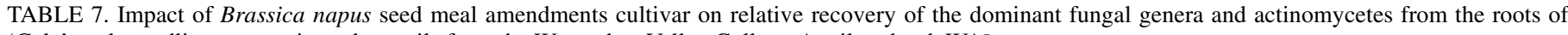
'Gala' apple seedlings grown in replant soils from the Wenatchee Valley College-Auvil orchard, WA ${ }^{\mathrm{z}}$

\begin{tabular}{|c|c|c|c|c|c|}
\hline Treatment & Cylindrocarpon & Fusarium & Pythium & Rhizoctonia & Actinomycetes \\
\hline Control & $19.6 \mathrm{~b}$ & $2.4 \mathrm{a}$ & $2.0 \mathrm{a}$ & $16.4 \mathrm{c}$ & $3.2 \mathrm{a}$ \\
\hline Pasteurization $\left(95^{\circ} \mathrm{C}\right)$ & $4.0 \mathrm{a}$ & $3.6 \mathrm{a}$ & $0 \mathrm{a}$ & $1.2 \mathrm{a}$ & $6.8 \mathrm{a}$ \\
\hline 0.1\% 'Dwarf Essex' & $8.8 \mathrm{a}$ & $3.2 \mathrm{a}$ & $0 \mathrm{a}$ & $9.6 \mathrm{~b}$ & $22.4 \mathrm{c}$ \\
\hline $0.1 \% \mathrm{C}$ & $21.6 \mathrm{~b}$ & $3.6 \mathrm{a}$ & $3.2 \mathrm{a}$ & $9.2 \mathrm{~b}$ & $14.4 \mathrm{~b}$ \\
\hline $1.0 \%$ 'Dwarf Essex' & $25.6 \mathrm{~b}$ & $21.6 \mathrm{~b}$ & $0.4 \mathrm{a}$ & $0 \mathrm{a}$ & $7.6 \mathrm{a}$ \\
\hline $1.0 \% \mathrm{C}$ & $40.0 \mathrm{c}$ & $4.4 \mathrm{a}$ & $21.5 \mathrm{~b}$ & $1.1 \mathrm{a}$ & $4.4 \mathrm{a}$ \\
\hline
\end{tabular}

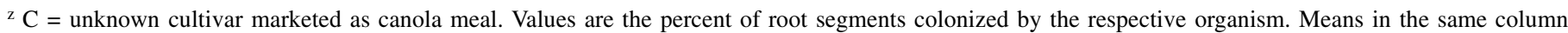
followed by the same letter are not significantly different $(P=0.05)$ based on the Student-Newman-Keuls test. 
infection by Rhizoctonia spp. was significantly reduced or eliminated by this treatment. It is plausible that changes in soil microbial community structure may have led to the observed disease suppression. Application of 'Dwarf Essex' seed meal at a rate of $0.1 \%$ significantly increased populations of total bacteria and fluorescent pseudomonads. Likewise, increased recovery of Fusarium spp. and actinomycetes from apple roots was observed in soils that received this low seed meal amendment rate, as well as at higher amendment rates. The role of various elements of these microbial groups in the suppression of Rhizoctonia spp. is plausible based on previous reports $(1,14,16,17,24)$.

Due to an apparent broad spectrum of activity, there has been interest in determining the potential for adverse impact of glucosinolate-containing plant residues on nontarget soil microorganisms. Muehlchen et al. (19) noted a reduction in root nodulation of pea roots grown in white mustard-amended soils relative to that observed in nonamended soils. In contrast, Scott and Knudsen (25) reported that soil incorporation of a B. napus 'Dwarf Essex' green manure crop had no apparent impact on nodulation of pea roots by $R$. leguminosarum, and did not affect total viable counts of bacteria or fluorescent pseudomonads recovered from the pea rhizosphere. In our study, dramatic changes in total bacteria, fluorescent pseudomonads, and actinomycete populations were recorded in response to B. napus seed meal amendments. Regardless of glucosinolate content, soil populations of total bacteria and actinomycetes increased in response to seed meal amendments of 0.1 or $1.0 \%$ ( $\mathrm{vol} / \mathrm{vol})$, but fluorescent pseudomonad populations declined dramatically in soils amended at rates of $1.0 \%$ or higher. Similar impacts on fluorescent pseudomonad populations in orchard replant soils were obtained in the field (M. Mazzola, unpublished data).

The potential negative impact of $B$. napus seed meal amendments on populations of fluorescent Pseudomonas spp. may have significant implications for incorporating these amendments with wheat cover cropping as a means to promote apple growth on replant sites. Wheat cultivation of replant soils suppresses populations of Pythium spp. in orchard replant soils both in greenhouse (16) and in field trials (M. Mazzola, unpublished data). Given the ability of $B$. napus seed meal amendments to effectively control $R$. solani and Pratylenchus penetrans, but its failure to reduce apple root infection by Pythium spp., it is plausible that enhanced control of apple replant disease may be obtained through integration of these two practices. Certain fluorescent pseudomonad genotypes are suspected to have a role in the wheat-induced suppression of the fungal complex that incites apple replant disease (7,16,17; Y.-H. Gu and M. Mazzola, unpublished data). The demonstrated impact of B. napus seed meal amendments on populations of this bacterial group suggest that optimal integration of these practices will require the use of seed meal amendments at a rate below $1 \%(\mathrm{vol} / \mathrm{vol})$. Trials are needed to determine the appropriate application sequence of these practices, as well as amendment and seeding rates for optimal control of apple replant disease.

\section{ACKNOWLEDGMENTS}

This work was supported, in part, by the Cooperative State Research, Education, and Extension Service, U.S. Department of Agriculture, under agreement 98-34103-6414 and the Washington Tree Fruit Research Commission.

\section{LITERATURE CITED}

1. Alabouvette, C., Schippers, B., Lemanceau, P., and Bakker, P. A. H. M. 1998. Biological control of Fusarium wilts. Pages 15-36 in: PlantMicrobe Interactions and Biological Control. G. J. Boland and L. D. Kuykendall, eds. Marcel Dekker, Inc., New York.

2. Angus, J. F., Gardner, P. A., Kirkegaard, J. A., and Desmarchelier, J. M. 1994. Biofumigation: Isothiocyanates released from Brassica roots inhibit growth of the take-all fungus. Plant Soil 162:107-112.

3. Bending, G. D., and Lincoln, S. D. 2000. Inhibition of soil nitrifying bacteria communities and their activities by glucosinolate hydrolysis products. Soil Biol. Biochem. 32:1261-1269.

4. Brown, P. D., and Morra, M. J. 1997. Control of soil-borne plant pests using glucosinolate-containing plants. Adv. Agron. 61:167-231.

5. Davis, R. M., Nunez, J. J., Vargas, R. N., Weir, B. L., Wright, S. D., and Munier, D. J. 1996. Metam-sodium kills beneficial soil fungi as well as cotton pests. Calif. Agric. 50:42-44.

6. Gamliel, A., and Stapleton, J. J. 1993. Characterization of antifungal volatile compounds evolved from solarized soil amended with cabbage residues. Phytopathology 83:899-905.

7. Gu, Y.-H., and Mazzola, M. 2001. Impact of carbon starvation on stress resistance, survival in soil habitats and biocontrol ability of Pseudomonas putida strain 2C8. Soil Biol. Biochem. (In press.)

8. Kücke, M. 1993. The efficiency of rapeseed oil cake as fertilizer. Agribiol. Res. 46:269-276.

9. Lewis, J. A., and Papavizas, G. C. 1974. Effect of volatiles from decomposing plant tissues on pigmentation, growth and survival of Rhizoctonia solani. Soil Sci. 118:156-163.

10. Manici, L. M., Lazzeri, L., Baruzzi, G., Leoni, O., Galletti, S., and Palmieri, S. 2000. Suppressive activity of some glucosinolate enzyme degradation products on Pythium irregulare and Rhizoctonia solani in sterile soil. Pest. Manag. Sci. 56:921-926.

11. Manici, L. M., Lazzeri, L., and Palmieri, S. J. 1997. In vitro fungitoxic activity of some glucosinolates and their enzyme-derived products toward plant pathogenic fungi. J. Agric. Food Chem. 45:2768-2773.

12. Mazzola, M. 1998. Elucidation of the microbial complex having a causal role in the development of apple replant disease in Washington. Phytopathology 88:930-938.

13. Mazzola, M. 1998. Towards the development of sustainable alternatives for the control of apple replant disease in Washington. Pages 8.1-8.3 in: Proc. Annu. Int. Res. Conf. on Methyl Bromide Alternatives and Emissions Reductions. Methyl Bromide Alternatives Outreach, Fresno, CA.

14. Mazzola, M. 1999. Transformation of soil microbial community structure and Rhizoctonia-suppressive potential in response to apple roots. Phytopathology 89:920-927.

15. Mazzola, M., Elfving, D. C., and Granatstein, D. M. 1999. Impact of biological, cultural and narrow-spectrum biocide treatments on growth of apple in orchard replant soils. (Abstr.) Phytopathology 89(suppl.):S50.

16. Mazzola, M., and Gu, Y.-H. 2000. Impact of wheat cultivation on microbial communities from replant soils and apple growth in greenhouse trials. Phytopathology 90:114-119.

17. Mazzola, M., and Gu, Y.-H. 2000. Phyto-management of microbial community structure to enhance growth of apple in replant soils. ACTA Hortic. 532:73-78.

18. Mazzola, M., and Levesque, C. A. 1999. Diversity in species composition and sensitivity to metalaxyl among populations of Pythium from apple. (Abstr.) Phytopathology 89(suppl.):S50.

19. Muehlchen, A. M., Rand, R. E., and Parke, J. L. 1990. Evaluation of crucifer green manures for controlling Aphanomyces root rot of peas. Plant Dis. 74:651-654.

20. Munnecke, D. E., Domsch, K. H., and Eckert, J. W. 1962. Fungicidal activity of air passed through columns of soil treated with fungicides. Phytopathology 52:1298-1306.

21. Papavizas, G. C. 1966. Suppression of Aphanomyces root rot of peas by cruciferous soil amendments. Phytopathology 56:1071-1075.

22. Patrick, Z. A., Toussoun, T. A., and Snyder, W. C. 1963. Phytotoxic substances in arable soils associated with decomposition of plant residues. Phytopathology 53:152-161.

23. Ramirez-Villapudua, J., and Munnecke, D. E. 1988. Effect of solar heating and soil amendments of cruciferous residues on Fusarium oxysporum f. sp. conglutinans and other organisms. Phytopathology 78:289295.

24. Rothrock, C. S., and Gottlieb, D. 1984. Role of antibiosis of Streptomyces hygroscopicus var. geldanus to Rhizoctonia solani in soil. Can. J. Microbiol. 30:1440-1447.

25. Scott, J. S., and Knudsen, G. R. 1999. Soil amendment effects of rape (Brassica napus) residues on pea rhizosphere bacteria. Soil Biol. Biochem. 31:1435-1441.

26. Simon, A., and Ridge, E. H. 1974. The use of ampicillin in a simplified selective medium for the isolation of fluorescent pseudomonads. J. Appl. Bacteriol. 37:459-460.

27. Smolinska, U., Morra, M. J., Knudsen, G. R., and Brown, P. D. 1997. Toxicity of glucosinolate degradation products from Brassica napus seed meal toward Aphanomyces euteiches f. sp. pisi. Phytopathology 87: 77-82.

28. Toyota, K., Ritz, K., Kuninaga, S., and Kimura, M. 1999. Impact of fumigation with metam sodium upon soil microbial community structure 
in two Japanese soils. Soil Sci. Plant Nutr. 45:207-223.

29. Vera, C. L., McGregor, D. I., and Downey, R. K. 1987. Detrimental effects of volunteer Brassica on production of certain cereal and oilseed crops. Can. J. Plant Sci. 67:983-995.

30. Walker, G. E., and Morey, B. G. 1999. Effect of brassica and weed manures on abundance of Tylenchulus semipenetrans and fungi in citrus orchard soil. Aust. J. Exp. Agric. 39:65-72.

31. Willett, M., Smith, T. J., Peterson, A. B., Hinman, H., Stevens, R. G., Ley, T., Tvergyak, P., Williams, K. M., Maib, K. M., and Watson, J. W. 1994. Growing profitable apple orchards in replant sites: An interdisciplinary team approach in Washington state. HortTechnology 4:175-181. 